\title{
22. BASALTIC HYALOCLASTITES FROM HOLE 396B, DSDP LEG 46
}

\author{
Hans-Ulrich Schmincke, ${ }^{1}{ }^{2}$ Paul T. Robinson, ${ }^{3}$ Walter Ohnmacht, ${ }^{1}$ and Martin F. J. Flower ${ }^{1}$
}

\begin{abstract}
During Leg 46 a 90-meter-thick sequence of loose, sand-size, glassy basaltic debris (hyaloclastite) with some associated broken-pillow breccia was encountered beneath 175 meters of pillowed basalt. The presence of bedding in some of the hyaloclastites, the high ratio of sideromelane to crystalline basalt (up to $60 \%$ ), and the high degree of brecciation and vesiculation of overlying and underlying pillow breccias all indicate that the clastic unit is a sedimentary deposit that existed before drilling. This conclusion is confirmed by the high rate of bit penetration in this interval and by the geophysical log of the hole.

The high ratio of glass to crystalline basalt and the relative chemical homogeneity of the glass in the bedded hyaloclastite suggest that the clastic processes were roughly synchronous with eruption, and that the particles were not transported far from the site of brecciation. Spalling of pillow rinds to produce "spallation" shards is believed to be the major process of formation of sideromelane shards, but implosion of pillows and granulation of lava may also have occurred. The process of fragmentation of tachylite shards is unknown. Sideromelane in the sediments is extremely fresh, suggesting that the clastic unit was largely sealed off from percolating sea water and hence remained relatively dry since formation about $13 \mathrm{~m} . \mathrm{y}$. ago. This interpretation is supported by downhole temperature measurements.
\end{abstract}

\section{INTRODUCTION}

Hole 396B was drilled approximately $150 \mathrm{~km}$ east of the Mid-Atlantic Ridge at $22^{\circ} 59.14^{\prime} \mathrm{N}$ and $43^{\circ} 30.90^{\prime} \mathrm{W}$. Basaltic basement, approximately 13 m.y. old, was penetrated beneath 255 meters of sediment. Pillow basalts make up the upper 175 meters of basement; the lower 90 meters consist of largely unconsolidated sand-size clastic sideromelane and slightly crystallized basalt particles with rare indurated hyaloclastite and pillow fragments. The clastic material has been briefly described in a preliminary account (Shipboard Scientific Crew, 1976).

The clastic sequence, the thickest ever encountered during oceanic basement drilling, poses many questions regarding styles of submarine eruptions, present crustal models, and alteration processes. In our study we have attempted to answer the following specific questions: Is the clastic debris primary or a result of drilling? Was it concentrated and accumulated by sedimentary or by igneous processes? Can the distance to the source and the lateral extent of the layer be determined? What is the importance of this sequence in terms of constructional processes of mid-ocean ridges? What is the significance of the extraordinary freshness of the sideromelane shards, which are about 13 m.y. old?

\footnotetext{
'Institut für Mineralogie der Ruhr-Universität, 4630 Bochum, West Germany.

${ }^{2}$ Sabbatical address: Department of Geological Sciences, University of California, Santa Barbara, California.

${ }^{3}$ Department of Earth Sciences, University of California, Riverside, California.
}

\section{STRATIGRAPHY AND THICKNESS}

The shipboard party divided the clastic sequence into four lithologic units (5 to 8). Unit 5 (Cores 23 through 26 ) is carbonate-cemented breccia and sparsely phyric pillow basalt; Unit 6 (Cores 26 through 31 ) is predominantly loose sand-size clastic debris with rare pillow fragments; Unit 7 (Core 32 ) is predominantly pillow fragments of porphyritic basalt; and Unit 8 (Core 33) is again loose clastic material, mostly sand-size basalt. In the shipboard description and in a preliminary note (Shipboard Scientific Crew, 1976) the term gravel was used for the loose clastic debris. The term is misleading, however, unless it is understood purely in terms of grain size. Moreover, means of nearly all clastic samples studied by us are in the sand-size range, so in this paper we use the term hyaloclastite, or indurated hyaloclastite, for the clastic material.

We have divided the clastic sequence into the following lithologic units: upper pillow breccia (Cores 23 through 29), upper hyaloclastite (Cores 30 and 31), lower plagioclasephyric pillow breccia (Core 32 ), and lower hyaloclastite (Core 33). Recovery was very low in most cores (zero in Cores 27, 29, and 31 ; less than $1 \%$ in Cores 25, 26, and 28; and from $7.4 \%$ to a maximum of $20 \%$ in all other cores).

The upper pillow breccia (especially Cores 23 and 24 ) differs markedly from the overlying pillow basalts, even though these latter basalts are more vesicular, more brecciated, and more altered than basalts higher in the section. The upper pillow breccias in Cores 23 through 27 are almost aphyric; the lower units contain more phenocrysts, especially plagioclase, but in irregularly varying amounts. The 
most highly phyric unit is the bedded hyaloclastite of Core 30. Sand-size hyaloclastites predominate in Cores 30 and 33; Cores 23, 24, and 32 contain a significant portion of broken-pillow breccia. It is difficult to say how much finegrained hyaloclastite is present in the intervals represented by Cores 23 to 29 and 31 to 32 . Until Core 30, a liner was not used in the core catcher to retrieve the loose sand-size clastic debris. As a result, much loose debris may have been lost, and we do not know whether the entire 90-meter-thick section or only the lower 20 to 30 meters is made up largely of sand-size particles.

We have investigated six samples, each about 25 grams, of loose particles of different grain size from Core 30 (Samples 131, 133, and 134) and Core 33 (Samples 138, 139, and 140) and a slice of the larger of two indurated hyaloclastite fragments from Core 30 . To compare shapes of shards, we also studied sand-size basaltic debris formed by steam blasting during drilling in Makaopuhi lava lake (Hawaii).

\section{CLASTIC COMPONENTS OF THE UNCONSOLIDATED HYALOCLASTITES}

Clastic components of the hyaloclastites were identified by binocular microscope examination, by thin-section examination of grain mounts of different size grades, and by scanning electron microscope examination of selected samples. Six main components were distinguished: (1) sideromelane; (2) spherulitic tachylite to variolitic basalt; (3) crystalline basalt; (4) cemented aggregates; (5) single carbonate, zeolite, or chalcedony(?) particles; and (6) crystal fragments of plagioclase and olivine.

Sideromelane is the main component in Core 30 (Samples 131,133 , and 134) and the second most common component in Core 33 (Samples 138, 139, and 140) (Table 1; Plate 1 , Figures 1 and 2 ). The glass is typically clear and transparent, and contains rare spherulites and very rare small decorated vesicles (Plate 2, Figure 3). Small skeletal crystallites of plagioclase and/or olivine, as well as sparse phenocrysts of plagioclase and olivine, are also present. Particles are blocky, equant, and angular, and become somewhat more elongate with decreasing grain size (Plate 2, Figures 1 and 2; Plate 3, Figures 1-4). This change in shape with degree of fragmentation can be predicted from incipient fractures that tend to split blocky particles into more tabular slivers.

Most sideromelane fragments show no microscopic signs of palagonitization (Table 1). Very faint discolored rims are present on a few fragments, but more extensive palagonitization is rare.

Spherulitic tachylite to variolitic basalt fragments make up the most abundant component in Core 33 (Plate 1, Figure 1) and the second most abundant component in Core 30 (Plate 1, Figure 2). This material ranges from completely black, unstructured tachylite to spherulitic and variolitic basalt in which small plagioclase microlites are set in a brown devitrified base. Fragments are generally blocky to equant, but with more irregular edges than those of sideromelane clasts. Vesicles are also slightly more abundant than in sideromelane. Although a few fragments are transitional between completely clear sideromelane and completely opaque tachylite, distribution is distinctly bimodal and it is easy to assign particles to one of the groups. Such a population of particles would be expected from fragmentation of the outer part of a pillow, where the transition between the sideromelane rind and the underlying spherulitic and tachylitic zone is usually quite abrupt.

Completely crystalline basalt particles are rare (Table 1). The crystalline fragments are fine-grained basalt composed of plagioclase, clinopyroxene, olivine, and titanomagnetite.

Nearly all the investigated samples contain one or more aggregates of small, generally sliver-like sideromelane particles. Such aggregates are probably more abundant in the original material-they would be easily destroyed by sieving. Most aggregates are irregular in shape and less than 2 $\mathrm{mm}$ in diameter. They contrast with the loose particles, in that none contain tachylite. Carbonate is the predominant cement in the aggregates. It not only binds the particles together, but fills small fractures and, in a few cases, partially replaces sideromelane particles. The next most common cement is birefringent "palagonite"' (smectite?) which occurs as a coating around the glass particles. Iron hydroxide, phillipsite, and chalcedony(?) are other rare cements.

The cementing minerals in the aggregates may also occur, though rarely, as isolated mineral particles in the loose material. Crystal fragments of plagioclase and olivine, the common phenocryst phases in the sideromelane, are also present.

\section{GRAIN-SIZE DISTRIBUTION OF UNCONSOLIDATED HYALOCLASTIC MATERIAL}

Grain-size analyses of the six samples of unconsolidated material were done by hand sieving. Medians range from about 3 to $1 \mathrm{~mm}$, and most fall in the coarse sand range (Figure 1). Thus, the loose debris, if cemented, would be called coarse basaltic sandstone or hyaloclastite. Sorting in all analyzed samples is very good. It must be remembered, however, that these data reflect only the grain-size distribution in the plastic liner of the core catcher. Fine-grained particles may have been lost during pull-out of the core barrel, and the clastic material may have been somewhat contaminated by "drilling debris," as discussed below.

Samples from Core 30 are finer grained than those from Core 33 (Figure 1). Samples from both cores show systematic changes in composition with grain size (Tables 1 and 2; Figures 2 and 3). In all samples, the abundance of spherulitic tachylite and variolitic basalt decreases with decreasing grain size. Sideromelane increases with decreasing grain size, although at grain sizes below about $0.125 \mathrm{~mm}$ it may decrease again because of the increasing proportion of plagioclase and olivine crystal fragments concentrated in the finest material.

\section{INDURATED HYALOCLASTITE}

A slightly indurated but friable hyaloclastite fragment, about $6 \mathrm{~cm}$ in maximum diameter, was recovered within the loose material of Core 30 . It consists of angular particles; the median size of most material is in the range of fine to medium sand. Particles larger than $1 \mathrm{~mm}$ are rare, as are silt-size particles; thus, sorting is excellent. The fragment consists of three main layers (Plate 3, Figure 1). The coarsest layer, $1.5 \mathrm{~cm}$ thick, is strongly graded from coarse sand, with a few elongate fragments up to $3 \mathrm{~mm}$ long, to uniform fine sand. On the basis of this grading, we interpret 
TABLE 1

Petrographic Constituents of Hyaloclastite in Different Size Grades

\begin{tabular}{|c|c|c|c|c|c|c|c|c|c|c|}
\hline $\begin{array}{l}\text { Sample Number } \\
\text { and Grain } \\
\text { Size Interval } \\
(\mathrm{mm})\end{array}$ & $\begin{array}{l}\text { Fresh } \\
\text { Sidero- } \\
\text { melane }\end{array}$ & $\begin{array}{l}\text { Siderome- } \\
\text { lane with } \\
\text { Incipient } \\
\text { Palagonit- } \\
\text { ization }\end{array}$ & Tachylite & $\begin{array}{l}\text { Tachylite } \\
\text { with } \\
\text { Plagioclase } \\
\text { Microlites }\end{array}$ & $\begin{array}{l}\text { Completely } \\
\text { Crystalline } \\
\text { Basalt }\end{array}$ & $\begin{array}{l}\text { Cemented } \\
\text { Hyalo- } \\
\text { clastite }\end{array}$ & $\begin{array}{c}\text { Single } \\
\text { Carbonate } \\
\text { Particles }\end{array}$ & $\begin{array}{l}\text { Single } \\
\text { Olivine } \\
\text { and Pla- } \\
\text { gioclase } \\
\text { Crystals }\end{array}$ & $\begin{array}{c}\text { Total } \\
\text { Number } \\
\text { of Grains } \\
\text { Counted }\end{array}$ & $\begin{array}{c}\text { Ratio } \\
\text { Sideromelane/ } \\
\text { Sideromelane \& } \\
\text { Tachylite }\end{array}$ \\
\hline $131,1-2$ & 45 & 6 & 37 & 9 & - & 4 & - & - & 99 & 0.53 \\
\hline $131,0.5-1$ & 85 & 7 & 48 & 9 & - & 3 & 3 & 1 & 156 & 0.62 \\
\hline $131,0.25-0.5$ & 161 & - & 68 & 23 & 5 & 1 & 2 & 3 & 263 & 0.64 \\
\hline $133,1-2$ & 27 & 7 & 32 & 12 & 1 & 5 & - & - & 84 & 0.44 \\
\hline $133,0.5-1$ & 88 & 15 & 52 & 13 & 1 & 2 & 1 & 1 & 173 & 0.61 \\
\hline $133,0.25-0.5$ & 258 & 29 & 155 & 34 & 4 & 4 & 5 & 5 & 494 & 0.60 \\
\hline $134,1-2$ & 25 & 4 & 23 & 14 & - & 1 & 1 & - & 68 & 0.44 \\
\hline $134,0.5-1$ & 79 & 8 & 45 & 9 & 1 & 1 & 1 & 1 & 145 & 0.62 \\
\hline $139,1-2$ & 11 & 4 & 24 & 10 & 1 & 2 & - & - & 52 & 0.31 \\
\hline $139,0.5-1$ & 45 & 4 & 78 & 47 & 1 & 4 & 4 & 4 & 187 & 0.28 \\
\hline $140,2-4$ & 15 & 2 & 9 & 20 & - & 1 & - & - & 47 & 0.37 \\
\hline $140,1-2$ & 49 & - & 65 & 30 & - & 4 & - & - & 158 & 0.34 \\
\hline
\end{tabular}

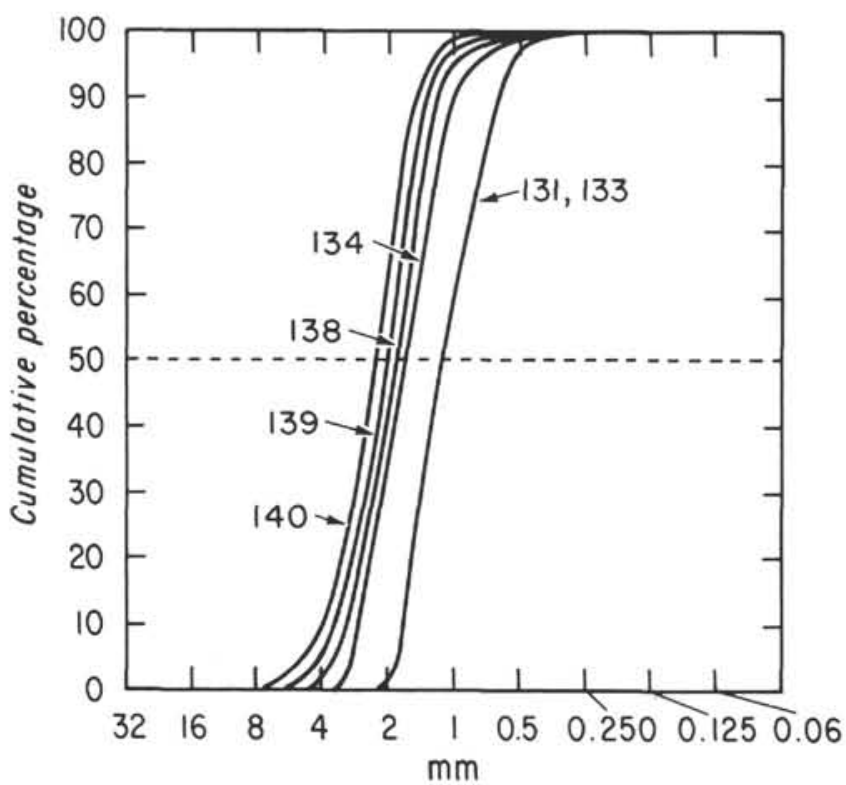

Figure 1. Cumulative grain-size distribution of six samples of loose clastic basaltic debris from Cores 30 and 33, showing the coarser grain size of Core 33 material.

the fine sand to be the top of the layer. The graded layer is overlain, with sharp contact, by a very fine grained layer, 5 to $8 \mathrm{~mm}$ in thickness, which has a slightly coarser central zone. This layer forms what appears to be a load cast about $1 \mathrm{~cm}$ wide and $3 \mathrm{~mm}$ deep into the underlying layer (Plate 3 , Figure 1). The fine-grained layer is in turn overlain, with sharp contact, by relatively uniform fine- to mediumgrained hyaloclastite.

Vesicles are nearly absent in the sideromelane shards in the bedded material. Plagioclase phenocrysts, as single crystal fragments or enclosed in sideromelane, make up about 10 to 15 volume per cent. These exhibit oscillatory zoning (An78-88), and many contain inclusions of transparent sideromelane. Olivine makes up 1 to 2 modal per cent, and biogenic debris, such as foraminifers, makes up less than 1 per cent. Tachylitic, spherulitic, variolitic, or crystalline basalt fragments are absent from the bedded hyaloclastite.
The sideromelane particles in the bedded hyaloclastite have different shapes, depending on their grain size; most shards above about $1 \mathrm{~mm}$ are subequant and angular, but have round corners except where freshly broken (Plate 3 , Figures 2 and 3). With decreasing grain size, the shards become increasingly flaky or sliver-like with length/width ratios up to about 20 (Plate 3, Figures 2 and 4). Many of the larger equant fragments have curved fractures, suggesting that some such fragments have broken down into flaky shards.

A similar relationship between grain shape and grain size exists for the mineral fragments. Plagioclase crystals larger than about $1 \mathrm{~mm}$ are nearly equant, but they become increasingly flaky with decreasing grain size. Generally, however, crystals and glass are separated from each other, indicating that the interface between them is a plane of weakness. Curved fractures in the glass commonly start at the interface between sideromelane and crystals; this suggests that the boundary is a preferred zone of breakage.

We completed 17 microprobe analyses for major elements on 12 glass shards within the bedded hyaloclastite. Up to three analyses were done initially on single shards, to test for homogeneity. We found that the shards are homogeneous within analytical error, so did only one analysis on the remaining shards. All analyses fall into one of two chemically similar but distinct groups, called $\mathrm{Z} 1$ and Z2 (Table 3). Both are more similar to each other in most elements than to the other chemical groups of Leg 46 glasses (Flower et al., this volume), especially with respect to $\mathrm{SiO}_{2}$ $\mathrm{Al}_{2} \mathrm{O}_{3}$. The most pronounced differences between $\mathrm{Z1}$ and $\mathrm{Z} 2$ are in $\mathrm{TiO}_{2}$ and $\mathrm{CaO}$ and, less noticeably, in $\mathrm{FeO}$, $\mathrm{Al}_{2} \mathrm{O}_{3}$, and $\mathrm{K}_{2} \mathrm{O}$. Group $\mathrm{Z} 1$ is the most common and includes the larger shards, although data are still sparse. The petrologic significance of these chemical data is discussed elsewhere (Flower et al., this volume). Here, we emphasize that the glass shards in the bedded hyaloclastite are derived from two distinct but similar basaltic magma batches.

Less than 10 per cent of the sideromelane shards are altered to a relatively homogeneous yellow, isotropic "palagonite." Palagonitization of particles has generally gone to completion, and partly spherulitic particles appear to have been preferentially palagonitized over the smaller particles. In some palagonitized shards, the interiors are 
TABLE 2

Grain-Size Analyses and Composition of Hyaloclastites, Cores 30 (Samples 131, 133, 134) and 33 (Samples 138, 139, 140)

\begin{tabular}{|c|c|c|c|c|c|c|}
\hline $\begin{array}{l}\text { Grain Size } \\
(\mathrm{mm})\end{array}$ & $\begin{array}{c}\text { Weight } \\
\text { Percentage }\end{array}$ & Sideromelane & $\begin{array}{c}\text { Crystalline } \\
\text { Basalt }\end{array}$ & Aggregates & Carbonate & $\begin{array}{c}\text { Single } \\
\text { Crystals }\end{array}$ \\
\hline
\end{tabular}

\section{Sample 131}

2-4

1-2

$0.5-1$

$0.25-0.5$

$0.125-0.25$

$<0.125$

Sample 133

2-4

1-2

$0.5-1$

0.25-0.5

$0.125-0.25$

$<0.125$

Sample 134

2-4

1-2

0.5-1

$0.25-0.5$

$0.125-0.25$

$<0.125$

Sample 138

4-8

2-4

1-2

$0.5-1$

$0.25-0.5$

$0.125-0.75$

Sample 139

4-8

2-4

$1-2$

$0.5-1$

0.25-0.5

$0.125-0.25$

0.125

Sample 140

$\begin{array}{lr}4-8 & 10 \\ 2-4 & 48 \\ 1-2 & 40 \\ 0.5-1 & 2\end{array}$

5

55
70
75
80
60
55

25
27
22
13
20
5

10
1
-
-
-
-

$\begin{array}{rr}10 & - \\ 1 & 1 \\ 1 & 2 \\ 2 & 5 \\ 5 & 15 \\ 10 & 30\end{array}$

$\begin{array}{rl}2 & 45 \\ 60 & 5 \\ 37 & 60 \\ - & 60 \\ 1 & 60 \\ - & 50\end{array}$

$$
\begin{aligned}
& 40 \\
& 37 \\
& 34 \\
& 34 \\
& 10 \\
& -
\end{aligned}
$$

10
5
2
-
-
-

$\begin{array}{rr}2 & - \\ 2 & 2 \\ 2 & 2 \\ 2 & 4 \\ 5 & 25 \\ 10 & 45\end{array}$

40

45

46$$
40
$$$$
40
$$$$
1
$$$$
55
$$$$
\begin{aligned}
& 55 \\
& -
\end{aligned}
$$

$\begin{array}{rr}5 & 15 \\ 40 & 43 \\ 50 & 40 \\ 3 & 40 \\ - & 50 \\ - & 60\end{array}$

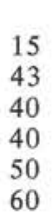

7
47
48
2
-
1
-

40
-
38
32
30
50
40

-
75
50
52
50
45
30

10
6
-
-
-
-

$\begin{array}{ll}- & - \\ - & - \\ 1 & 1 \\ 2 & 3 \\ 2 & 3 \\ - & -\end{array}$

dissolved completely, whereas the margins have been transformed into crystalline phases.

It is unclear why some particles are completely palagonitized whereas the majority of shards are completely fresh. Incipient palagonitization can be seen along some cracks and crystal/glass boundaries, but most such boundaries are unaffected. Preservation of delicate features of some palagonitized shards indicates that palagonitization must have occurred after deposition. Plagioclase and olivine crystal fragments are completely fresh.

\section{DISCUSSION}

We will discuss the origin of the hyaloclastic unit in terms of the questions posed in the introduction:
1) Is the clastic debris primary in origin or is it a product of drilling? One of the first interpretations of the clastic debris made on board ship — and indeed a suggestion made commonly when similar debris has been encountered on other DSDP legs-is that reaming by the drill bit causes comminution of basalt, particularly when a new drill bit is forced through a hole that is tapered downward. It is thus important to establish reliable criteria for distinguishing between such "secondary" comminution processes and those that occur during formation of the oceanic crust.

Several lines of evidence convincingly demonstrate that most of the clastic debris recovered during Leg 46 is primary, although we cannot exclude the possibility that a small portion of the material is a result of drill reaming: (a) The 


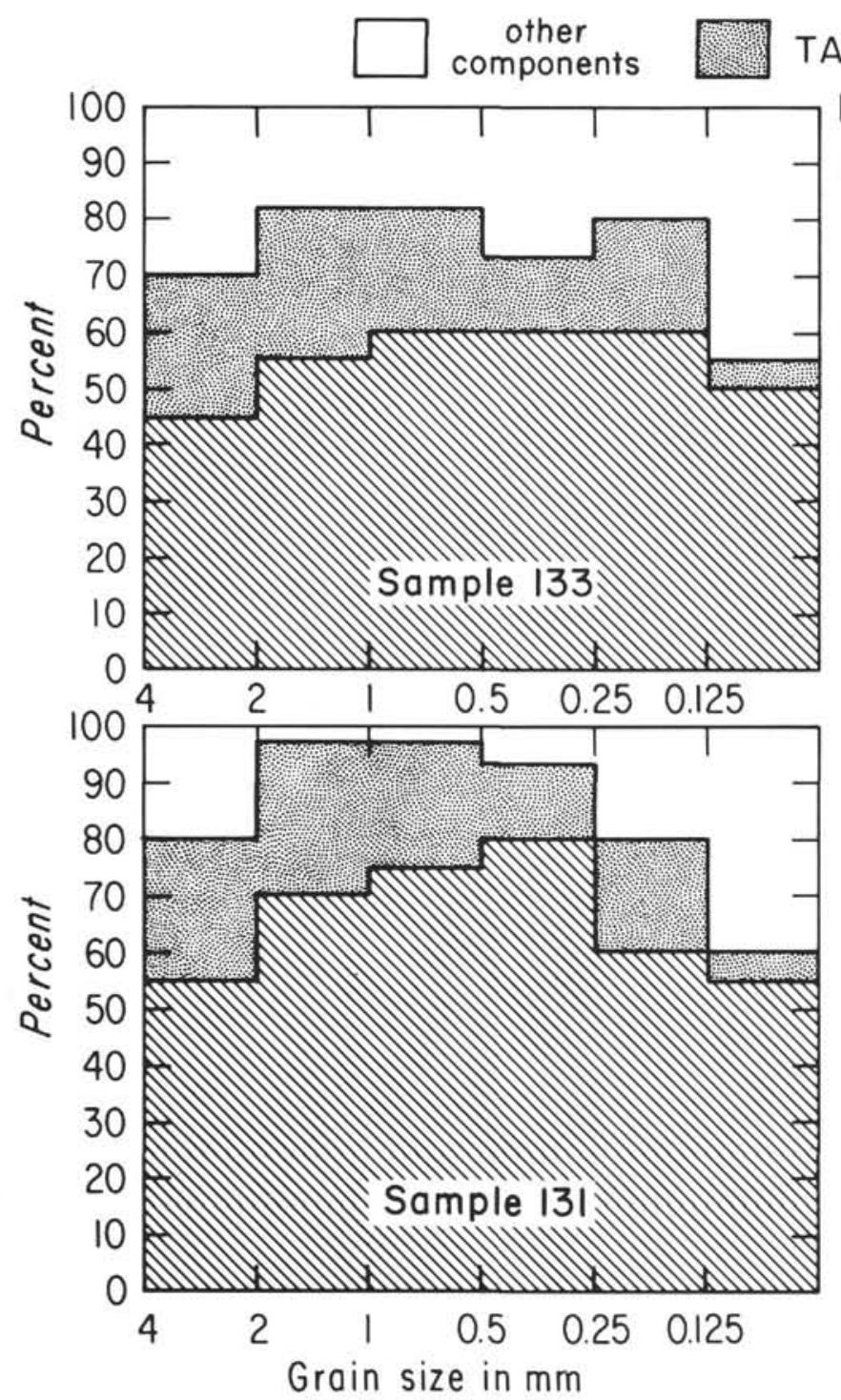

ACHYLITE $\mathbb{E}$ SIDEROMELANE

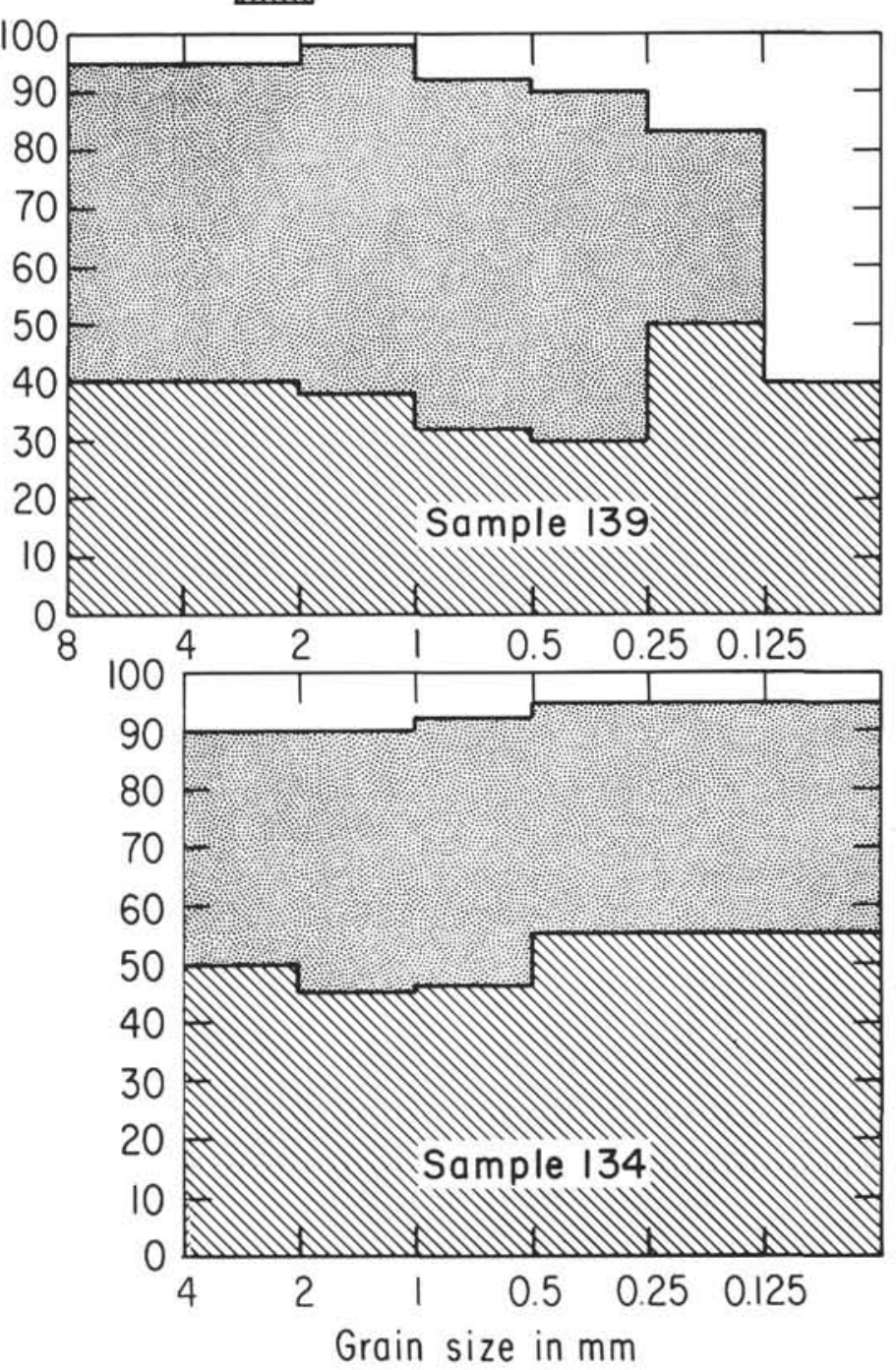

Figure 2. Histograms of four samples of unconsolidated clastic basaltic debris, showing the difference in grain size among the samples and the increase in the sideromelane/tachylite ratio in the finer grained samples. Note the higher per cent of crystals in the finest grained material.

presence of bedded, partly cemented hyaloclastite (Plate 3, Figures 1 through 4 ) is proof that at least some of the material was a clastic deposit before drilling. Moreover, small pieces of slightly cemented material occur commonly throughout Cores 30 and 33. (b) The drilling rate greatly accelerated when the clastic layer was encountered, and drilling rates were similar to those commonly encountered in "sand" (in the driller's terminology) (see Shipboard Summary, this volume). (c) The logging profile (Shipboard Summary, this volume) conclusively shows an interval of high porosity coinciding with the clastic layer, and porosities in this interval are much higher than in the pillow basalt drilled above the clastic layer. (d) The high proportion of glass relative to crystalline basalt is good evidence that the clastic debris did not result from simple fragmentation of pillows by drill reaming. Pillows are typically about $50 \mathrm{~cm}$ in diameter in the pillowed units, a size fairly representative of pillows in general. The pillows have only thin sideromelane rinds, about $0.5 \mathrm{~cm}$ thick, in agreement with data by Moore (1975). Thus, fragmentation of an entire pillow would yield about 2 per cent glass. This contrasts strongly with the hyaloclastites from Hole 396B, which contain between 30 and 60 per cent glass (Table 1; Plate 1, Figures 1 and 2). It is unlikely that drill reaming would have preferentially fragmented glassy pillow rinds. Moreover, the sideromelane of pillow rinds from the overlying pillows is always partially palagonitized, in strong contrast to the fresh sideromelane shards in the hyaloclastite. (e) The occurrence of small pillows, less than $10 \mathrm{~cm}$ in diameter, within the loose debris is also circumstantial evidence for a primary origin. Similar pillows were not found in the overlying sequence, and this suggests differences in eruptive processes between the two intervals. Finally, beginning with Core 23, coarser grained, cemented, pillow-rind breccias are abundant compared to the overlying pillow units, providing strong evidence that eruptive and/or depositional processes had profoundly changed.

From the above evidence we conclude that the clastic material of Cores 30 and 33 is definitely primary in origin, i.e., it constituted a clastic unit in the basaltic oceanic crust 


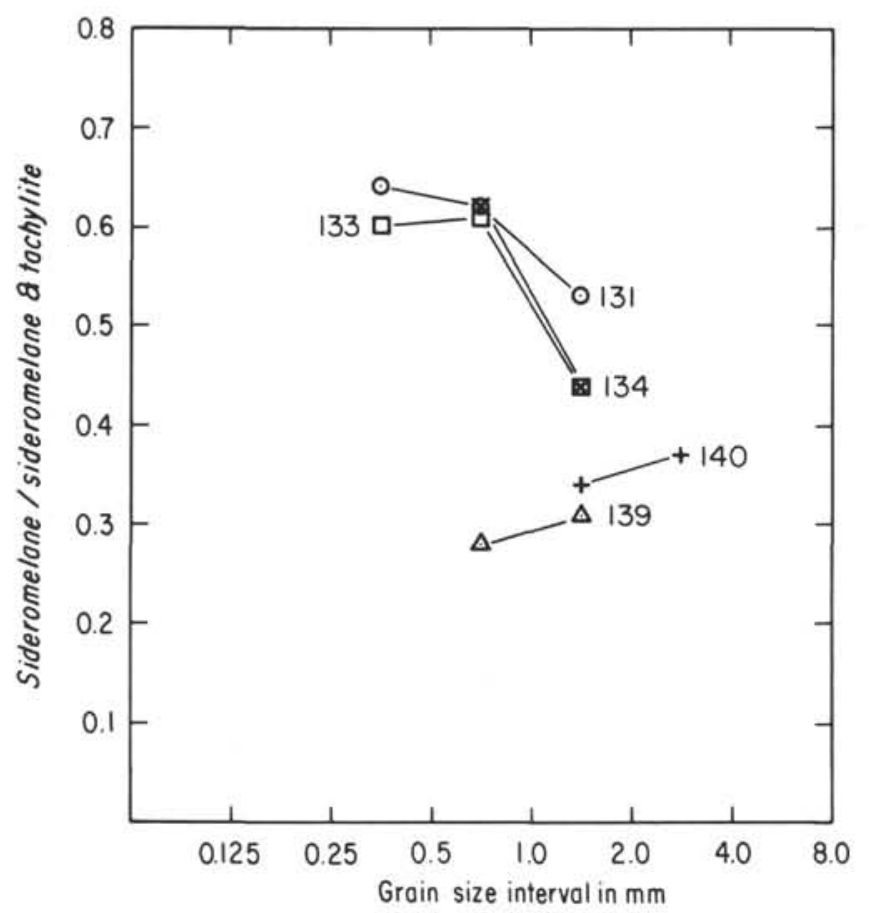

Figure 3. Plot of grain size versus sideromelane/(sideromelane + tachylite) ratio for unconsolidated samples. Note increase in sideromelane with decreasing grain size in samples from Core $30(131,133,134)$ and slight decrease in sideromelane with decreasing grain size in samples from Core $33(139,140)$. Note also the higher sideromelane/tachylite ratios in samples from Core 30, compared with those from Core 33.

before drilling. The clastic material may have been contaminated by basaltic debris comminuted during drilling, but we think this is minor based on the above evidence.

2) Are the primary clastic processes associated with eruptions or are they due to faulting, mass wasting (such as fault scarp debris), or erosion? What distance were the particles transported? That the sideromelane shards in the bedded hyaloclastite belong to only two different but similar chemical groups strongly suggests that these shards were winnowed out of one, or at the most two, volcanic piles, and probably formed during the eruption. We reason that, in view of the great chemical variability in the ocean crust both vertically and laterally within a few tens to a few hundreds of meters, material winnowed out of fault scarp debris would probably be chemically and mineralogically much more heterogeneous than the material in the bedded hyaloclastite. All the glassy shards and some of the basaltic particles are very angular and have sharp edges, indicating a nearby source and a lack of weathering prior to transport. The high proportion of glass to crystalline basalt is strong evidence for comminution of glassy pillow rinds during eruption. Faulting, just as drill reaming, should produce debris with only a small glass fraction.

The almost total absence of crystalline basalt in the bedded hyaloclastite and its relative abundance in the loose debris presents an unsolved problem. Part of the difference may be a consequence of the difference in the grain size between the loose and consolidatd material. We have noted
TABLE 3

Average Chemical Compositions, With Standard Deviations, for Each Oxide of Glass Groups 1 and 2 From the Bedded Hyaloclastite

\begin{tabular}{|c|c|c|}
\hline BO Number & $1350 \mathrm{a}$ & $1350 \mathrm{~b}$ \\
\hline Core-Section & \multicolumn{2}{|c|}{$30-1$} \\
\hline Interval, cm & \multicolumn{2}{|c|}{$84-86$} \\
\hline $\begin{array}{l}\text { Shipboard } \\
\text { Chem. Unit }\end{array}$ & $\mathrm{C}$ & $\mathrm{C}$ \\
\hline Glass Group & $\mathrm{Z} 1$ & $\mathrm{Z} 2$ \\
\hline $\begin{array}{l}\mathrm{SiO}_{2} \\
\mathrm{TiO}_{2}\end{array}$ & $\begin{aligned} 49.39 & \pm 0.37 \\
1.52 & \pm 0.01\end{aligned}$ & $\begin{array}{r}49.63 \pm 0.40 \\
1.43: 0.02\end{array}$ \\
\hline $\begin{array}{l}\mathrm{Al}_{2} \mathrm{O}_{3} \\
\mathrm{FeO}^{*} \\
\mathrm{MnO} \\
\mathrm{MgO}\end{array}$ & $\begin{array}{r}16.15 \pm 0.19 \\
9.18 \pm 0.08 \\
0.15 \pm 0.04 \\
8.04 \pm 0.04\end{array}$ & $\begin{array}{r}16.38 \pm 0.16 \\
8,90 \pm 0.10 \\
0.14 \pm 0.04 \\
8.27 \pm 0.15\end{array}$ \\
\hline $\mathrm{CaO}$ & $11.17 \pm 0.02$ & $11.38 \pm 0.06$ \\
\hline $\mathrm{Na}_{2} \mathrm{O}$ & $3.08 \pm 0.02$ & $2.98 \pm 0.08$ \\
\hline $\mathrm{K}_{2} \mathrm{O}$ & $0.18 \pm 0.02$ & $0.16 \pm 0.01$ \\
\hline $\mathrm{P}_{2} \mathrm{O}_{5}$ & $0.21 \pm 0.08$ & $0.20 \pm 0.04$ \\
\hline $\mathrm{Cr}_{2} \mathrm{O}_{3}$ & $0.06 \pm 0.02$ & $0.07 \pm 0.03$ \\
\hline $\mathrm{NiO}$ & - & - \\
\hline $\mathrm{BaO}$ & - & - \\
\hline $\mathrm{SO}_{3}$ & $0.13 \pm 0.03$ & $0.12 \pm 0.03$ \\
\hline Total & 99.26 & 99.66 \\
\hline $\begin{array}{l}\text { No. of } \\
\text { Analyses }\end{array}$ & 11 & 6 \\
\hline
\end{tabular}

above that the ratio of glassy to crystalline basalt increases with decreasing grain size, and that the bedded hyaloclastite has a much smaller median size than the loose debris. Even in samples of comparable grain size, however, the proportion of crystalline basalt in the loose debris is much higher. Perhaps the crystalline basalt is a contaminant produced by drill reaming of the overlying pillow and breccia units. Such an origin would explain why some of the crystalline basalt is altered whereas the glass is extremely fresh. The close association of the hyaloclastic material with extensively brecciated basalt layers is further evidence of a primary origin.

3) What is the nature of the submarine clastic processes? We have presented evidence that the hyaloclastites are primary deposits formed by submarine eruptions. Four main mechanisms have been suggested to explain the formation of volcaniclastic material under sub-aquatic conditions: (a) Vesiculation caused by expansion of magmatic gases; (b) steam explosions; (c) spalling of pillow rinds; and (d) direct granulation. We can exclude the first two processes because the probable depth of extrusion of the lavas (over $3000 \mathrm{~m}$ below sea level) was such that the confining pressures were too high to allow vaporization of sea water and significant exsolution of magmatic volatiles. This conclusion is supported by the paucity of vesicles in both the glass and crystalline basalt, although a few particles may have formed by vesiculation (Plate 2, Figure 3). Rittmann (1960) proposed that ash-size basaltic particles can be produced in situ by breakage of pillow rinds during submarine extrusion, and he coined the term hyaloclastite for such material. In many pillow sequences the uppermost part of glassy pillow rinds if often partly flaked off or wedged apart, and the fractures are wholly or partly filled with cal- 
cite or zeolites. Although this wedging apart may have occurred after accumulation of the pillows, the brittle fractures in the quenched rind most likely formed during extrusion.

Another process that may form nonvesicular sideromelane shards when lava is erupted under, or flows into, water is granulation caused by thermal shock. Observations from lava flows entering water show that granulation may occur under special conditions. Moore et al. (1973) observed that only very thin lava streams become granulated upon entering the water. Some clastic disruption can also occur in larger lava flows, but in these cases steam eruptions are involved. Flake-like shards may also form during quenching of basalt lava by water (Plate 1, Figures 3 and 4) (see also Carlisle, 1963).

Unfortunately, no criteria are available at present that permit us to distinguish between flaky sideromelane shards formed from spalling of glassy pillow rinds and those produced by granulation. That feldspar crystal fragments in the bedded hyaloclastite have flake-like shapes similar to those of sideromelane shards suggests that cracking was so rapid that fractures were propagated through glass and crystals alike. The relative abundance of tachylite indicates that processes other than spalling and granulation have been operative, and it is possible that some of the tachylite is attributable to drill-bit reaming.

Regardless of the exact mechanism of formation, the abundance of hyaloclastic material in Hole 396B suggests somewhat unusual eruptive processes. Drilling data, ocean-bottom photographs, and direct observations by submersibles have shown that pillow lavas are by far the most common mode of extrusion of basalt lava on the sea floor. We suggest that the hyaloclastite material can be accounted for by very rapid extrusion of lava onto the sea floor, building up steep-sided piles of pillow basalt. Frequent slumping of pillows on the sides of the mounds, followed by periodic spurts of lava, could lead to rapid spalling of pillow rinds and granulation of glassy material. Normal currents, or convection currents caused by heating of sea water during eruption, could winnow the ash-size spallation and granulation shards and deposit them nearby, either on the flanks of such piles-as the presence of small pillows might suggest - or a short distance away. The great thickness of the clastic sequence might be explained by either of two hypotheses: (a) the clastic deposit may represent a mound of granulated material with some small pillows which formed as a constructional feature around a local vent, or (b) the clastic material may have been winnowed from a nearby pillow lava pile and deposited in front of a pillow pile or in an adjacent basin or depression. We are unable to explain the absence of crystalline basalt fragments in the indurated hyaloclastite and their common presence in the loose material. Two likely possibilities are caving of material from the overlying breccia and reaming by the drill bit, as discussed above. It is also possible that some crystalline material may have been supplied from a different source or by different currents. The presence of foraminifers in the bedded hyaloclastite, and the bedding itself, are good evidence for the presence of currents.

4) What is the significance of the hyaloclastite layer in the formation of oceanic Layer 2? The occurrence of a 90-meter-thick layer of rather loose clastic volcanic material of low density in the upper oceanic crust may help account for the low seismic velocities found in Layer 2a. Although we suspect that this layer has a limited lateral extent, we believe that similar deposits occur elsewhere, and so the overall volume of clastic material in Layer 2a may be large. Similar clastic basaltic material has been found in other drill holes (Legs 37 and 49); this suggests that clastic volcanic layers may make up a significant portion of the oceanic crust.

If our suggestion is correct that unusually rapid extrusion produced the thick pile of clastic material, we may speculate that such events are episodic. Study of the oceanic crust during the past few years by drilling and by submersible operations has revealed that constructional processes are typically episodic, in terms of volcanic and tectonic activity. The data presented here suggest that intensity of volcanic activity or eruptive mechanisms may also vary significantly. Whereas most extrusive activity on the sea floor results in pillow lava and associated breccias and rarer flows, volcanic activity may sporadically be so intense that significant amounts of sand-size particles are produced. So far, nothing has been discovered to suggest that the postulated high intensity was caused either by unusual chemical composition or by high content of volatile material in the magmas; such factors are often responsible for very intense activity in subaerial volcanoes. The intense activity may thus have been controlled by tectonic activity along the median rift. If so, such activity may have been relatively widespread along the rift at this particular time.

The striking freshness of the sideromelane and the minor cementation by secondary minerals contrasts strongly with the overlying pillow sequence, even though reactive surfaces, porosities, and permeabilities are much higher in the hyaloclastic unit. This general absence of palagonite may be a consequence of any of several possible causes: (a) Sideromelane may have originally had palagonite rims which were broken off by winnowing during drilling or transport. This hypothesis can be excluded because palagonitization always tends to round off corners, and the sideromelane shards have sharp corners and sides. Moreover, particles in the indurated hyaloclastites do not differ in angularity and freshness from the loose particles. (b) Palagonitization may have been prevented by an early phase of carbonate cementation which was later dissolved. This is also unlikely, because carbonate is generally the latest cementing phase and it tends to replace sideromelane as well as phenocryst phases. (c) The glass shards have been sealed off from sea water. If the glass shards had been in contact with sea water either on the sea floor or after burial within the crust, they should all have become marginally palagonitized (Moore, 1966; Bryan and Moore, 1977). The absence of palagonite must thus mean an essentially dry environment (except for local spots) for the last 13 m.y. Such an interpretation sounds quite implausible, but it is the only one presently compatible with the evidence. Such a dry space could have been caused by rapid burial of the clastic material which thus sealed it off from percolating water. This sealing off may have resulted from rapid palagonitization and cementation of the inter-pillow spaces in the overlying lavas, or it may reflect rapid sedimentation, or both. 
If such sealing can be shown to have occurred, it would help explain one of the major finds of several DSDP cruises, i.e., that alteration does not increase downward as postulated in some models for the oceanic crust. These models call for wholesale downward percolation of sea water throughout the crust, except at a few places of upwelling hydrothermal cells. It may be that rapid sedimentation and thorough cementation of the upper 100 to 200 meters of the oceanic crust may form an impermeable cap under which little alteration takes place. Supporting evidence for the suggestion that the hyaloclastites remained dry comes from temperature measurements in Hole 396B. Erickson (this volume) concludes that cold sea water was moving downward into the hyaloclastite layer because of the rather low temperatures encountered.

\section{ACKNOWLEDGMENTS}

Our work was supported by grants (Schm 250/16-18) from the Deutsche Forschungsgemeinshaft, which we gratefully acknowledge. The manuscript was written while H.-U.S. was supported by a stipend from the VW foundation. We thank D. Pierce for help with the scanning electron photomicrographs. D. A. Swanson supplied us with a sample of Makaopuhi "steam blast" drilling debris. This is contribution No. 80 from the Biogeology Clean Lab, University of California, Santa Barbara.

\section{REFERENCES}

Bryan, W.B. and Moore, J.G., 1977. Compositional variations of young basalts in the Mid-Atlantic Ridge rift valley near lat $36^{\circ} 49^{\prime}$ N, Geol. Soc. Am. Bull., v. 88, p. 556-570.

Carlisle, D., 1963. Pillow breccias and their aquagene tuffs, Quadra Island, British Columbia, J. Geol., v. 71, p. 48-71.

Moore, J.G., 1966. Rate of palagonitization of submarine basalt adjacent to Hawaii. U.S. Geol. Survey Prof. Paper 550-D, p. D163-D171.

Moore, J.G., 1975. Mechanism of formation of pillow lava, Am. Scientist, v. 63, p. 269-277.

Moore, J.G., Phillips, R.L., Grigg, R.W., et al., 1973. Flow of lava into the sea, 1969-1971, Kilauea Volcano, Hawaii, Geol. Soc. Am. Bull., v. 84, p. 537-546.

Rittmann, A., 1960. Vulkane und ihre Tätigkeit. Enke, Stuttgart, p. 335.

Shipboard Scientific Crew, 1976. Glass-rich basaltic sand and gravel within the oceanic crust at $22^{\circ} \mathrm{N}$, Nature, v. 262, p. 768-770. 